\title{
In Vitro Evaluation of Biofield Treatment on Cancer Biomarkers Involved in Endometrial and Prostate Cancer Cell Lines
}

\author{
Mahendra Kumar Trivedi ${ }^{1}$, Shrikant Patil ${ }^{1}$, Harish Shettigar ${ }^{1}$, Mayank Gangwar ${ }^{2}$ and Snehasis Jana ${ }^{2 *}$ \\ ${ }^{1}$ Trivedi Global Inc., 10624 S Eastern Avenue Suite A-969, Henderson, NV 89052, USA \\ ${ }^{2}$ Trivedi Science Research Laboratory Pvt. Ltd., Hall-A, Chinar Mega Mall, Chinar Fortune City, Hoshangabad Rd., Bhopal-462026, Madhya Pradesh, India
}

\begin{abstract}
Increasing cancer rates particularly in the developed world are associated with related lifestyle and environmental exposures. Combined immunotherapy and targeted therapies are the main treatment approaches in advanced and recurrent cancer. An alternate approach, energy medicine is increasingly used in life threatening problems to promote human wellness. This study aimed to investigate the effect of biofield treatment on cancer biomarkers involved in human endometrium and prostate cancer cell lines. Each cancer cell lines were taken in two sealed tubes i.e. one tube was considered as control and another tube was subjected to Mr. Trivedi's biofield treatment, referred as treated. Control and treated samples were studied for the determination of cancer biomarkers such as multifunctional cytokines viz. interleukin-6 (IL-6) and tumor necrosis factor-alpha (TNF- $\alpha$ ), interleukin-2 receptor (IL-2R), prostate specific antigen (PSA), and free prostate specific antigen (FPSA) concentrations using ELISA assay on day 10. Experimental results showed a significant reduction of IL-6 level in endometrium (12\%) and prostate $(98.8 \%)$ cancer cell lines while a significant increase was observed in TNF- $\alpha$ level in endometrium $(385 \%)$ and prostate $(89.8 \%)$ cancer cell lines as compared to control. No alteration of PSA level was observed in biofield treated endometrium and prostate cell line. Similarly, no alterations were evident in IL-2R and FPSA levels in endometrium and prostate cell lines after biofield treatment as compared to control. In conclusion, results suggest that biofield treatment has shown significant alterations in the level of cytokines (IL- 6 and TNF- $\alpha$ ) in both endometrium and prostate cancer cell lines.
\end{abstract}

Keywords: Biofield treatment; Cancer biomarker; ELISA; TNF- $\alpha$; IL-6; Prostate cancer; Endometrium cancer

\section{Introduction}

Cancer has the potential to invade or spread to other parts of the body which involves abnormal cell growth. Endometrium cancer (EC) is the most common type of uterine cancer which starts in the endometrium. EC cases are increasing worldwide and even higher in developing countries [1]. However, physicians have developed new diagnostic techniques and treatments, which results in decreased reported cases of cancer in developing countries [2]. Endometrioid adenocarcinoma is the most common type of EC with clear cell histologic appearance made up of cells in glands that look much like the normal uterine lining (endometrium) [3]. The survival rate in an early and advanced stage of diagnosed EC is less than five years [4], and chances of about $50 \%$ recurrence after postoperative therapy is still high [5]. Most common cancer in male, especially in the western world causing death is prostate cancer (PC). In the United States, approximately 238,590 new cases of PC with a death of about 29,720 cases [6]. Progression of PC is through a multi-step development such as involvement of growth factor, cytokines, and hormones [7].

Role of immune cells estimation in microenvironment of tumor has been well established. On the primary hormonal basis, these immune cells in tumor respond to produce a wide range of cytokines, chemokines, and growth factors. Interleukins (IL-1, IL-6, and IL8), tumor necrosis factor- $\alpha$ (TNF- $\alpha$ ), vascular endothelial growth factor (VEGF), granulocyte-macrophage colony stimulating factor (GM-CSF), and colony stimulating factor-1 (CSF-1) are the common inflammatory markers used in diagnosis [8]. IL-6 and TNF- $\alpha$, are considered as the major cancer biomarkers of a network involved in EC and PC development with multiple biological characteristics $[9,10]$. TNF- $\alpha$, is a multifunctional cytokine which plays a major role in cell death and survival, as well as in inflammation and immunity. TNF- $a$ increases susceptibility to heat-induced cell death (apoptosis) in a time- dependent manner, an important protective cellular activity. IL-6 is a pleiotropic cytokine, which exerts inflammatory and immune response on various cell types including prostate carcinomas. Serum IL-6 is the surrogate marker in the clinical stage of PC. High concentrations of serum IL- 6 are associated with an increased risk of death in patients with cancer. Expression of IL-2R, PSA and FPSA are the robust biomarkers in predicting a diagnosis assay for prostate cancer. Normally, IL-2R and IL-6 concentrations were significantly higher in prostate cancer tissue than in normal tissue.

In the last 70 years, cancer treatment strategies have rapidly increased. Chemotherapy always associated with attached side effects such as hair loss, nausea, vomiting, cognitive dysfunction, change in sexual function and adverse impact on patient's quality of life [11]. Surgery is still the main treatment strategy for early-stage diagnosis of cancer, but for advanced and reoccurrence cases multimodality therapies like radiations and chemotherapy being frequently used $[12,13]$. Increased use of alternative integrative medicine approaches have been recently introduced and used to promote wellness and minimize side effects from cancer. In the year $2007,40 \%$ U.S. population has used natural products as a complementary and alternate medicine (CAM) [14]. National Center for Complementary and Alternative Medicine

*Corresponding author: Snehasis Jana, Trivedi Science Research Laboratory Pvt. Ltd., Hall-A, Chinar Mega Mall, Chinar Fortune City, Hoshangabad Rd. Bhopal- 462026, Madhya Pradesh, India, Tel: +91-755-6660006; E-mail: publication@trivedisrl.com

Received June 24, 2015; Accepted July 30, 2015; Published August 03, 2015

Citation: Trivedi MK, Patil S, Shettigar H, Gangwar M, Jana S (2015) In Vitro Evaluation of Biofield Treatment on Cancer Biomarkers Involved in Endometrial and Prostate Cancer Cell Lines. J Cancer Sci Ther 7: 253-257. doi:10.4172/19485956.1000358

Copyright: (c) 2015 Trivedi MK, et al. This is an open-access article distributed under the terms of the Creative Commons Attribution License, which permits unrestricted use, distribution, and reproduction in any medium, provided the original author and source are credited. 
(NCCAM), now defined biofield therapies in the subcategory of energy therapies as one of the five complementary medicine domains. Biofield is the name given to the electromagnetic field that permeates and surrounds living organisms. It is the scientifically preferred term for the biologically produced electromagnetic and subtle energy field that provides regulatory and communication functions within the organism. Recent studies on cancer research suggest that instead of using other complementary and alternate medicine, cancer patients received highest benefit with energy medicine [15]. The concept of human bioenergy has its origin thousands of year back, till date many recent biofield therapies are in practice for their possible therapeutic potentials such as enhanced personal well-being in cancer patient [16], improved functional ability of arthritis patient [17], decreased pain and anxiety [18]. However, many other significant inhibitory effects on the cancer cell model have been published which suggest that biofield treatment could be a new and effective treatment approach for cancer $[19,20]$. Mr. Mahendra Trivedi's unique biofield treatment (The Trivedi's effect ${ }^{\circ}$ ) has significantly studied in different fields. In agriculture, change on growth, characteristics, and yield of plants were reported after biofield treatment $[21,22]$. It has also significantly altered the crystalline and powder characteristics of metals $[23,24]$ and transformation of biofield energy has considerably altered the genotype and phenotypes of pathogenic microbes against antimicrobials [25-27]. This experiment was designed to evaluate the impact of biofield treatment on cancer biomarkers in endometrium and prostate cancer cell lines. Concentration of cytokines (i.e. TNF- $\alpha$ and IL-6), interleukin-2 receptor (IL-2R), prostate specific antigen (PSA), and free prostate specific antigen (FPSA) were estimated by using ELISA assay on day 10 after biofield treatment as compared to control.

\section{Materials and Methods}

\section{Experimental design}

Endometrium and prostate cancer cell lines, as stock stored cultures were procured for the experiment from department of laboratory medicine, P.D. Hinduja National Hospital \& Medical Research Centre, Mumbai. Enzyme-Linked Immuno-Sorbant Assay (ELISA) method was used for estimation of cytokines levels. Important cancer diagnostic biomarkers such as IL- 6 , TNF- $\alpha$, PSA (third generation), FPSA, and IL$2 \mathrm{R}$ of control and treated samples were estimated using ELISA kit as per manufacturer's instruction.

\section{Biofield treatment modalities}

Endometrium and prostate cancer cell lines were taken for biofield treatment. The first sets of both cancer cell line were considered as control. No treatment was given to this set. The second sets of both cancer cell line were handed over to Mr. Trivedi for biofield treatment under laboratory condition. Mr. Trivedi provided the biofield treatment through his energy transmission process to second sets of samples without touching the samples. After treatment, both treated samples were handed over in the same condition within an hour's time and stored at standard conditions for cytokines analysis after 10 days. Both the control and treated samples were analyzed after 10 days for difference in cancer biomarker as per the standard protocols. An optimum precautionary measure were taken in estimation of IL6 , TNF- $\alpha$, PSA (third generation), FPSA, and IL-2R throughout the experiment. The differences in tested cancer biomarkers level before and after the treatment were noted.

\section{Measurement of diagnostic cancer biomarkers}

ELISA was performed as per the manufacturer's instructions in control and treated sample to observe the impact of biofield treatment on concentration of biomarkers (IL-2R, IL-6, TNF- $\alpha$, PSA, and FPSA) [28]. ELISA principle started with capturing antibody, specific for a protein of interest, coated onto the wells of microplates. Control and biofield treated cell lysate samples were diluted and pipetted into the 96 micro wells titer plate. Buffer was added into each well and mixed gently for 30 seconds. The plate was covered and incubated for 60 minutes at room temperature as per manufacturer's instruction. Removed the incubation mixture from all wells followed by washing with distilled water for five times. During this incubation, protein of interest i.e., antigen (TNF- $\alpha$, IL-6, PSA, FPSA, and IL-2R) attached to the antibody. A secondary antibody was added to the wells after washing with buffer, which bound to immobilized protein captured during first incubation. Excess antibody was removed by washing with the help of wash buffer. After that, enzyme conjugate was added into each well, mixed gently for 10 seconds followed by incubation for 60 minutes at room temperature. A specific substrate solution was added into the well which was converted by the enzyme to form a detectable color. The intensity of the color produced was read spectrophotometrically which was directly proportional to the concentration of protein of interest present in the cell line samples. Control and treated sample values were recorded in picogram per milliliter (IL-6 and TNF- $\alpha$ : pg/ml), nano gram per milliliter (PSA and FPSA: ng/ml), and unit per milliliter (IL-2R-U/ml) [29]

\section{Results and Discussion}

Since prostate and endometrium cancers are most critical medical problems affecting major population, physician suggests chemoprevention strategies to reduce the incidence and mortality rate. However, there are scientific evidence and large number of in vitro studies already reported for biofield treatment and its effect in cancer cell lines $[19,20]$. The present study aimed to examine Mr. Trivedi's biofield treatment on cancer biomarkers associated with endometrium and prostate cancer. Previous studies indicated that there were an inhibitory effect of biofield energy on metastasis and immune responses on cancer cell models [30-33].

Results of control and treatment group, at day 10 are summarized in Table 1. In case of endometrium cell line, $12 \%$ reduction in IL-6 concentration was found in biofield treated group as compared to control. After biofield treatment, decreased level of IL-6 (3.52 pg/ $\mathrm{ml})$ was reported as compared to control $(4.0 \mathrm{pg} / \mathrm{ml})$. A highly significant increase in TNF- $\alpha$ (385\%) level was estimated in biofield treated endometrium cell line $(20.5 \mathrm{pg} / \mathrm{ml})$ as compared to control $(4.23 \mathrm{pg} / \mathrm{ml})$. A high increase in TNF- $\alpha$ level might be its association and binding with several other cells such as endothelial cells, which results in its high expression after biofield treatment as compared as control [34]. However, level of PSA, FPSA, and IL-2R did not show any alteration after biofield treatment as compared to control. In endometrial adenocarcinoma, cytokines promote tumor development by angiogenesis and mediating cell invasion. TNF- $\alpha$, pro-inflammatory cytokine biomarker exists as both soluble and membrane-integrated proteins activates signaling pathways, and is expressed on surface epithelium in cancer and endometrial adenocarcinoma. It promotes angiogenesis by the activation of NF- $\kappa \mathrm{B}$, a protein complex [35]. Apart from TNF- $\alpha$, IL- 6 is another pro-inflammatory cytokines whose level is upregulated in endometrial adenocarcinoma, which is associated with a poor prognosis [36]. Cancer research now proofed that dysregulation in immune system contributes to metastasis and lead to cell death. However, cancer progression is indicative by chronic inflammation which enhances angiogenesis and tissue metabolism results in cytokines release. Therefore, a significant alteration of important inflammatory 
Citation: Trivedi MK, Patil S, Shettigar H, Gangwar M, Jana S (2015) In Vitro Evaluation of Biofield Treatment on Cancer Biomarkers Involved in Endometrial and Prostate Cancer Cell Lines. J Cancer Sci Ther 7: 253-257. doi:10.4172/1948-5956.1000358

biomarkers (IL-6 and TNF- $\alpha$ ) in endometrium cancer cell line suggests that biofield treatment may affect metastasis, which results in alteration of pleiotropic and multifunctional cytokine levels. This finding is the first evidence that biofield therapy may alter the immune function in endometrium cancer.

Biofield treatment on prostate cancer cell line showed a significant reduction of as high as $98.8 \%$ in IL-6 level. After treatment, IL-6 concentrations showed less than $2 \mathrm{pg} / \mathrm{ml}$ as compared to control (165 $\mathrm{pg} / \mathrm{ml}$ ) in prostate cancer cells. Besides this, TNF- $\alpha$ level showed an increase of $89.8 \%$ in biofield treated group (i.e.7.59 $\mathrm{pg} / \mathrm{ml}$ ) as compared to control (less than $4.0 \mathrm{pg} / \mathrm{ml}$ ). Slight increase in level of PSA was observed in biofield treated prostate cell line as compared to control (Table 1). However, level of FPSA and IL-2R did not show any alteration after biofield treatment as compared to control. It suggests that the biofield treatment has significant impact only on cytokines level and not on receptors or antigens involved in metastasis. Above cytokines have the major involvement in prostate cancer development and elevated levels have been reported in prostate hyperplasia patients [37]. IL-6 and TNF- $\alpha$ levels have strong correlation in serum with hormone refractory prostate cancer as compared to normal cell [38]. Present study reported a significant reduction in IL-6 concentration and an increase in TNF- $\alpha$ level in prostate and endometrium cancer cell lines after biofield treatment (Figure 1). The result of the present study supports the already published literature with significant biofield effect on cancer cell lines. This study results are in agreement with the reported data [31-33] and verify the influence of biofield treatment on in vitro growth of prostate and endometrium cancer cell line with respect to cancer biomarkers level in control and treated samples.

Current cancer therapies have certain limitations, which include serious side effects such as enormous toxicity, altered immune system, and high treatment cost etc. Many ancient biofield therapies for cancer

\begin{tabular}{|c|c|c|c|c|c|c|c|}
\hline \multirow[t]{2}{*}{ S. No. } & \multirow[t]{2}{*}{ Biomarker } & \multicolumn{3}{|c|}{ Endometrium cell line } & \multicolumn{3}{|c|}{ Prostate cell line } \\
\hline & & Control & Treated & $\%$ change & Control & Treated & $\%$ change \\
\hline 1 & IL-2R (U/ml) & $<50.0$ & $<50.0$ & NC & $<50.0$ & $<50.0$ & NC \\
\hline 2 & IL-6 (pg/ml) & 4.0 & 3.52 & -12 & 165 & $<2.0$ & -98.8 \\
\hline 3 & TNF- $\alpha(p g / m l)$ & 4.23 & 20.5 & 385 & $<4.0$ & 7.59 & 89.8 \\
\hline 4 & $\mathrm{PSA}(\mathrm{ng} / \mathrm{ml})$ & $<0.003$ & $<0.003$ & NC & $<0.003$ & 0.003 & $\mathrm{NC}$ \\
\hline 5 & FPSA (ng/ml) & $<0.05$ & $<0.05$ & NC & $<0.05$ & $<0.05$ & NC \\
\hline
\end{tabular}

NC: No change; pg/ml: picogram per milliliter; ng/ml: Nano gram per milliliter; U/ml: Unit per milliliter; IL-2R: Interleukin-2 receptor; IL-6: Interleukin-6; TNF-a: Tumor necrosis factor alpha; PSA: Prostate specific antigen; FPSA: Free prostate specific antigen.

Table 1: Effect of biofield treatment on cancer biomarker concentration in endometrium and prostate cancer cell lines.

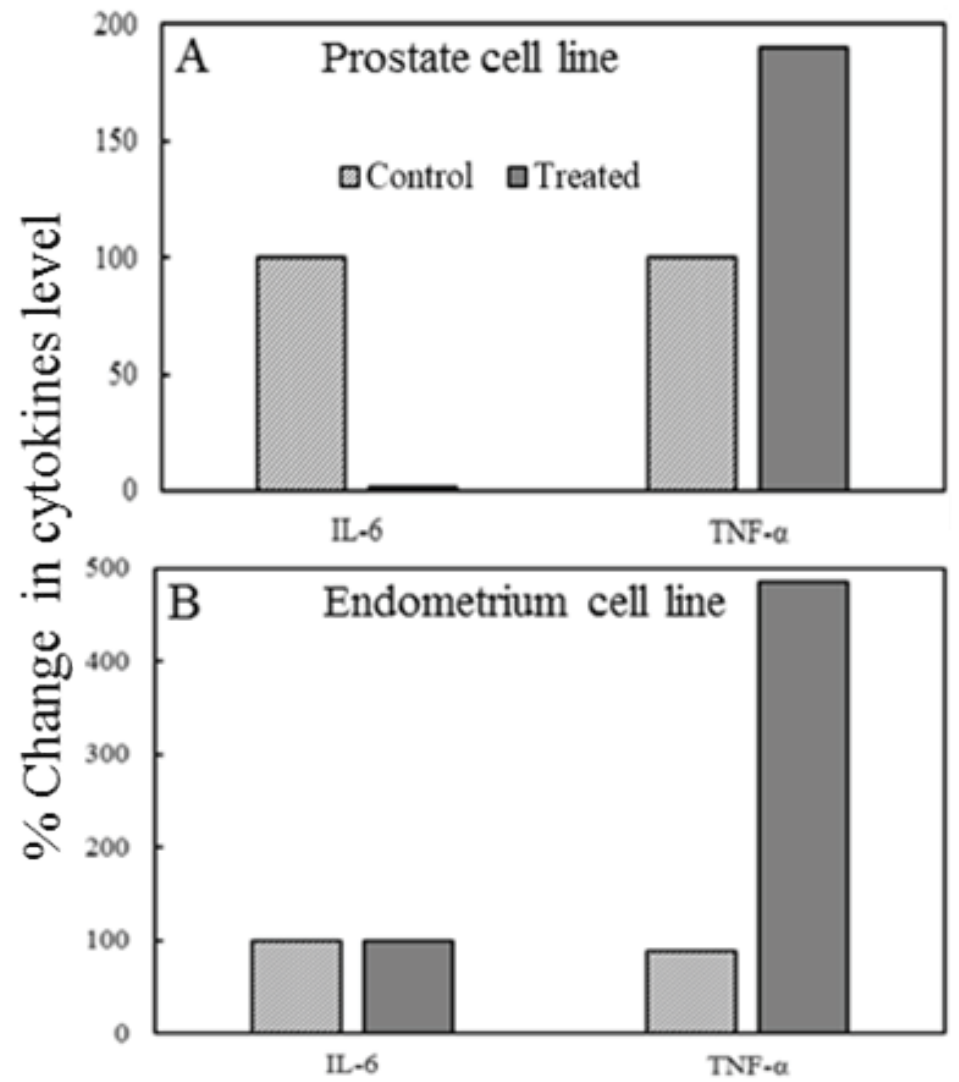

Figure 1: Percent change in cytokine level measured using ELISA assay on day 10 after biofield treatment in (a) endometrium cell line (b) prostate cell line. 
Citation: Trivedi MK, Patil S, Shettigar H, Gangwar M, Jana S (2015) In Vitro Evaluation of Biofield Treatment on Cancer Biomarkers Involved in Endometrial and Prostate Cancer Cell Lines. J Cancer Sci Ther 7: 253-257. doi:10.4172/1948-5956.1000358

are practiced around the world, among then Qigong therapy for cancer is very popular and scientifically studied $[39,40]$. Therefore, Mr. Trivedi's biofield treatment could be an effective and alternate approach for cancer with no side effects. Research on biofield therapies and its impact on cancer growth have been continuously studied by researchers, which might works as alternate and complementary medicine to prolong the life of cancerous patients along with quality life.

\section{Conclusion}

Study results conclude that biofield treatment has significantly altered the level of cytokines (IL- 6 and TNF- $\alpha$ ) in endometrium and prostate cancer cell lines as compared to control. Mr. Trivedi's biofield treatment showed a significant reduction in IL-6 level in prostate cancer cells (98.8\%) and endometrium cancer cell (12\%) as compared to control. There was also a significant increase of TNF- $\alpha$ concentration in both endometrium and prostate cancer cell lines. These data suggest that biofield treatment has significant impact in altering the cancer biomarkers especially two cytokine levels in both cancer cell lines.

\section{Acknowledgement}

Authors gratefully acknowledged to support of Trivedi science, Trivedi testimonials and Trivedi master wellness in this research work.

\section{Conflict of interest}

The authors declare that they have no competing interests.

\section{References}

1. Mirkin S, Pickar JH (2015) Selective estrogen receptor modulators (SERMs): a review of clinical data. Maturitas 80: 52-57.

2. Febbraro T, Lengyel E, Romero IL (2014) Old drug, new trick: repurposing metformin for gynecologic cancers? Gynecol Oncol 135: 614-621.

3. Siufi DF, Siufi Neto J, Abrão MS, Favero G (2014) Lymphadenectomy in early stage endometrial cancer: a critical review of the current literature. Tumori 100 : 477-485

4. Creasman WT, Odicino F, Maisonneuve P, Quinn MA, Beller U, et al. (2006) Carcinoma of the corpus uteri. FIGO 26th Annual Report on the results of treatment in gynecological cancer. Int J Gynaecol Obstet 95: S105-S143.

5. Randall ME, Filiaci VL, Muss H, Spirtos NM, Mannel RS, et al. (2006) Randomized phase III trial of whole-abdominal irradiation versus doxorubicin and cisplatin chemotherapy in advanced endometrial carcinoma: A gynecologic oncology group study. J Clin Oncol 24: 36-44.

6. Siegel R, Naishadham D, Jemal A (2013) Cancer statistics, 2013. CA Cancer J Clin 63: 11-30.

7. Huss WJ, Barrios RJ, Foster BA, Greenberg NM (2003) Differential expression of specific FGF ligand and receptor isoforms during angiogenesis associated with prostate cancer progression. Prostate 54: 8-16.

8. Joyce JA, Pollard JW (2009) Microenvironmental regulation of metastasis. Nat Rev Cancer 9: 239-252.

9. Smith DS, Catalona WJ, Herschman JD (1996) Longitudinal screening for prostate cancer with prostate-specific antigen. JAMA 276: 1309-1315.

10. Daiter E, Pampfer S, Yeung YG, Barad D, Stanley ER, et al. (1992) Expression of colony-stimulating factor- 1 in the human uterus and placenta. J Clin Endocrinol Metab 74: 850-858.

11. Kayl AE, Meyers CA (2006) Side-effects of chemotherapy and quality of life in ovarian and breast cancer patients. Curr Opin Obstet Gynecol 18: 24-28.

12. Alvarez Secord A, Havrilesky LJ, Bae-Jump V, Chin J, Calingaert B, et al. (2007) The role of multi-modality adjuvant chemotherapy and radiation in women with advanced stage endometrial cancer. Gynecol Oncol 107: 285-291.

13. Bruzzone M, Miglietta L, Franzone P, Gadducci A, Boccardo F (2004) Combined treatment with chemotherapy and radiotherapy in high-risk FIGO stage III-IV endometrial cancer patients. Gynecol Oncol 93: 345-352.

14. Barnes PM, Bloom B, Nahin RL (2008) Complementary and alternative medicine use among adults and children: United States, 2007. Natl Health Stat Report : 1-23.

15. Garland SN, Valentine D, Desai K, Langer C, Evans T, et al. (2013) Complementary and alternative medicine use and benefit finding among cancer patients. J Altern Complement Med 19: 876-881.

16. Giasson M, Bouchard $L$ (1998) Effect of therapeutic touch on the well-being of persons with terminal cancer. J Holist Nurs 16: 383-398.

17. Peck SD1 (1998) The efficacy of therapeutic touch for improving functional ability in elders with degenerative arthritis. Nurs Sci Q 11: 123-132.

18. Turner JG, Clark AJ, Gauthier DK, Williams M (1998) The effect of therapeutic touch on pain and anxiety in burn patients. J Adv Nurs 28: 10-20.

19. Yount G, Patil S, Dave U, Alves-dos-Santos L, Gon K, et al. (2013) Evaluation of biofield treatment dose and distance in a model of cancer cell death. J Altern Complement Med 19: 124-127.

20. Chen KW (2008) Inhibitory effects of bio-energy therapies on cancer growth World Sci Tech Modern Trad Chin Med 10: 144-152.

21. Shinde V, Sances F, Patil S, Spence A (2012) Impact of biofield treatment on growth and yield of lettuce and tomato. Aust J Basic Appl Sci 6: 100-105.

22. Sances F, Flora E, Patil S, Spence A, Shinde V (2013) Impact of biofield treatment on ginseng and organic blueberry yield. AGRIVITA J Agri Sci 35: 22-29.

23. Dabhade VV, Tallapragada RR, Trivedi MK (2009) Effect of external energy on atomic, crystalline and powder characteristics of antimony and bismuth powders. Bull Mat Sci 32: 471-479.

24. Trivedi MK, Patil S, Tallapragada RM (2012) Thought Intervention through biofield changing metal powder characteristics experiments on powde characterisation at a PM Plant, Springer Berlin Heidelberg, Editor: Wei Deng, Lecture Notes in Electrical Engineering-Future Control and Automation 173 247-252.

25. Trivedi MK, Patil S (2008) Impact of an external energy on Staphylococcus epidermis [ATCC-13518] in relation to antibiotic susceptibility and biochemical reactions-an experimental study. J Accord Integr Med 4: 230-235.

26. Trivedi MK, Patil S (2008) Impact of an external energy on Yersinia enterocolitica [ATCC-23715] in relation to antibiotic susceptibility and biochemical reactions: an experimental study. Internet J Alternat Med 6: 13.

27. Trivedi MK, Bhardwaj Y, Patil S, Shettigar H, Bulbule A (2009) Impact of an external energy on Enterococcus faecalis [ATCC-51299] in relation to antibiotic susceptibility and biochemical reactions-an experimental study. J Accord Integr Med 5: 119-130.

28. Stephens JC, Larkins A, James RF, Rathbone BJ (1996) Production of a monoclonal antibody against the $128 \mathrm{kDa}(\mathrm{CagA})$ protein of Helicobacter pylori. J Immunol Methods 190: 163-169.

29. Whitcomb BW, Perkins NJ, Albert PS, Schisterman EF (2010) Treatment of batch in the detection, calibration, and quantification of immunoassays in largescale epidemiologic studies. Epidemiology 21 Suppl 4: S44-50.

30. Running A (2015) Decreased Cortisol and Pain in Breast Cancer: Biofield Therapy Potential. Evid Based Complement Alternat Med 2015: 870640.

31. Yount G, Patil S, Dave U, Alves-dos-Santos L, Gon K, et al. (2013) Evaluation of biofield treatment dose and distance in a model of cancer cell death. J Altern Complement Med 19: 124-127.

32. Monzillo E, Gronowicz G (2011) New insights on therapeutic touch: a discussion of experimental methodology and design that resulted in significant effects on normal human cells and osteosarcoma. Explore (NY) 7: 44-51.

33. Gronowicz GA, Jhaveri A, Clarke LW, Aronow MS, Smith TH (2008) Therapeutic touch stimulates the proliferation of human cells in culture. J Altern Complement Med 14: 233-239.

34. Renard N, Lienard D, Lespagnard L, Eggermont AMM, Heimann R, et al. (1994) Early endothelium activation and polymorphonuclear cell invasion precede specific necrosis of human melanoma and sarcoma treated by intravascula high-dose tumour necrosis factor alpha (rTNF alpha). Int J Cancer 57: 656-663.

35. Seo KH, Lee HS, Jung B, Ko HM, Choi JH, et al. (2004) Estrogen enhances angiogenesis through a pathway involving platelet-activating factor-mediated nuclear factor-kB activation. Cancer Res 64: 6482-6488. 
Citation: Trivedi MK, Patil S, Shettigar H, Gangwar M, Jana S (2015) In Vitro Evaluation of Biofield Treatment on Cancer Biomarkers Involved in Endometrial and Prostate Cancer Cell Lines. J Cancer Sci Ther 7: 253-257. doi:10.4172/1948-5956.1000358

36. Slater M, Cooper M, Murphy CR (2006) Human growth hormone and interleukin-6 are upregulated in endometriosis and endometrioid adenocarcinoma. Acta Histochem 108: 13-18

37. Chen T, Wang LH, Farrar WL (2000) Interleukin 6 activates androgen receptormediated gene expression through a signal transducer and activator of transcription 3-dependent pathway in LNCaP prostate cancer cells. Cancer Res 60: 2132-2135.
38. Drachenberg DE, Elgamal AA, Rowbotham R, Peterson M, Murphy GP (1999) Circulating levels of interleukin- 6 in patients with hormone refractory prostate cancer. Prostate 41: 127-133.

39. Shen MX (1997) Qigong is an effective way to defeat cancer. China Qigong Science 5: 8-10.

40. Chen K, Yeung R (2002) Exploratory studies of Qigong therapy for cancer in China. Integr Cancer Ther 1: 345-370. 